\title{
17. VOLCANIC ASH AT SITE 584, JAPAN TRENCH ${ }^{1}$
}

\author{
Kantaro Fujioka, Ocean Research Institute, University of Tokyo \\ Jean-Paul Cadet, Département des Sciences de la Terre, Université d'Orléans \\ and \\ Jean-Claude Morin, Laboratoire de Géochimie des Roches Sédimentaires, Université de Paris Sud²
}

\begin{abstract}
Volcanogenic sediments were obtained from Site 584, located on the midslope of the Japan Trench. Occurrences of volcanic ash in the diatomaceous mudstones increase within sediments dated 6-3 Ma. The frequency pattern and the sediment accumulation rate obtained at Site 584 are similar to those of Site 440 and to those of Sites 438 and 439 , located on the upper slope basin. Explosive volcanism increased during the Pliocene and late Miocene in relation to the intrusion of Tertiary granites and uplift of the Tohoku Arc (northeastern Japan Arc). Hygromagmaphile element concentration shows that the glass does not belong to a unique series, and a comparison with Nankai Trough data distinguishes at least two different evolutionary lines.
\end{abstract}

\section{INTRODUCTION}

During Leg $87 \mathrm{~B}$, the middle slope of the Japan Trench was drilled at Site 584 , and $940 \mathrm{~m}$ of continuous sediments including many volcanic ash layers were obtained. Because the site is located on the lee side of the source area, the northeastern Japan Arc (Tohoku Arc), volcanic ash falls in this area (Fujioka, 1983b). As has already reported by Cadet and Fujioka (1980) and Fujioka and others (1980), volcanic ash in the upper slope basin sedimentary sequences at Sites 438 and 439 (Japan Trench) has two distinct Neogene maxima. We expect a similar pattern of the volcanogenic sediments at Site 584, although the geologic history will be slightly different (von Huene et al., 1980; Shipboard Scientific Party, 1983).

In this report, we present the basic data regarding the explosive volcanism in the onshore Tohoku Arc through Neogene times.

\section{Lithology}

Site 584, on the midslope of the Japan Trench forearc, is in a location similar to that of Site 440 (Fig. 1). Pleistocene to middle Miocene diatomaceous mud and mudstones $(941 \mathrm{~m})$ were drilled at Hole 584 (Shipboard Scientific Party, 1983), which is on multichannel seismic line ORI 78-3 (see fig. 1 in von Huene et al., 1980, and Fig. 2). Sediments are divided into four lithologic units depending on the variation in diatom content, abundance of thin silt beds, and other features (Fig. 3; Shipboard Scientific Party, 1983).

Unit 1 is a 4-m thick, Pleistocene, dark olive gray (5Y $4 / 2$ ) diatomaceous mud uncomformably overlying the olive gray diatomaceous mudstone of Unit 2 . Unit 3 consists of mudstones distinguished from Unit 2 by rela-

\footnotetext{
${ }^{1}$ Kagami, H., Karig, D. E., Coulbourn, W. T., et al., Init. Repts. DSDP, 87: Washington (U.S. Govt. Printing Office).

2 Addresses: (Fujioka) Ocean Research Institute, University of Tokyo 1-15-1, Minamidai, Nakano-ku, Tokyo 164, Japan; Jean-Paul Cadet, Département des Sciences de la Terre, Université d'Orléans, 45046 Orléans Cedex, France; Jean-Claude Morin, Laboratoire de Géochimie des Roches Sédimentaires, Université de Paris Sud, 91405 Orsay Cedex, France.
}

tively common, thin fine-sandstone-and-siltstone beds. Strata are inclined seaward and contain healed fractures. Unit 4 is a mudstone with less abundant diatoms and volcanic ash layers. Thin sandy beds (several $\mathrm{mm}$ to 1 $\mathrm{cm})$ are frequently encountered in this unit. Bioturbation is intense throughout all the cores.

A sedimentation rate curve based on paleomagnetic reversals and diatom biostratigraphy (Fig. 4) reveals periods of high accumulation rates from 13 to $11 \mathrm{Ma}$ and from 6 to $3 \mathrm{Ma}$, each followed by times of very low accumulation rates. The latter high sedimentation interval is identical to the rapid sedimentation period observed at Site 438 , drilled in the upper slope basin of Japan Trench.

\section{Volcanic Ash Layers}

More than 100 ashy intervals are encountered in the sedimentary intervals of Site 584 (see end-of-chapter Appendix). Their thicknessess and locations are described in both Figure 5 and the Appendix. Fujioka (1983b) classified the mode of occurrences of the volcanogenic sediments into three major types by visual core observation. In this core, we encountered all three types of volcanogenic sediments, that is, $\mathrm{D}, \mathrm{P}$, and $\mathrm{L}(\mathrm{D}=$ dispersed in sediments; $\mathrm{P}=$ pod or pocket; $\mathrm{L}=$ layer).

Lithology of the samples is homogeneous throughout the core but strongly bioturbated intervals are common (Shipboard Scientific Party, 1983). The thickness of the measurable volcanic ash layers is similar to and/or slightly less than that of ash layers at Site 438 (Fujioka, this volume).

Smear-slide data from the volcanic ash layers shows that ashy intervals contain more than $10 \%$ volcanic glass shards (Table 1), and stereographic photographs reveal that these are both pumice and bubble-wall type shards (Plate 1). At Site 584, the ratio of pumice of bubble-wall type glass is high compared to that at Site 436 , and low compared to that at Site 438, a result of the location of this site between Sites 438 and 436 relative to the ash source (Tohoku Arc). 


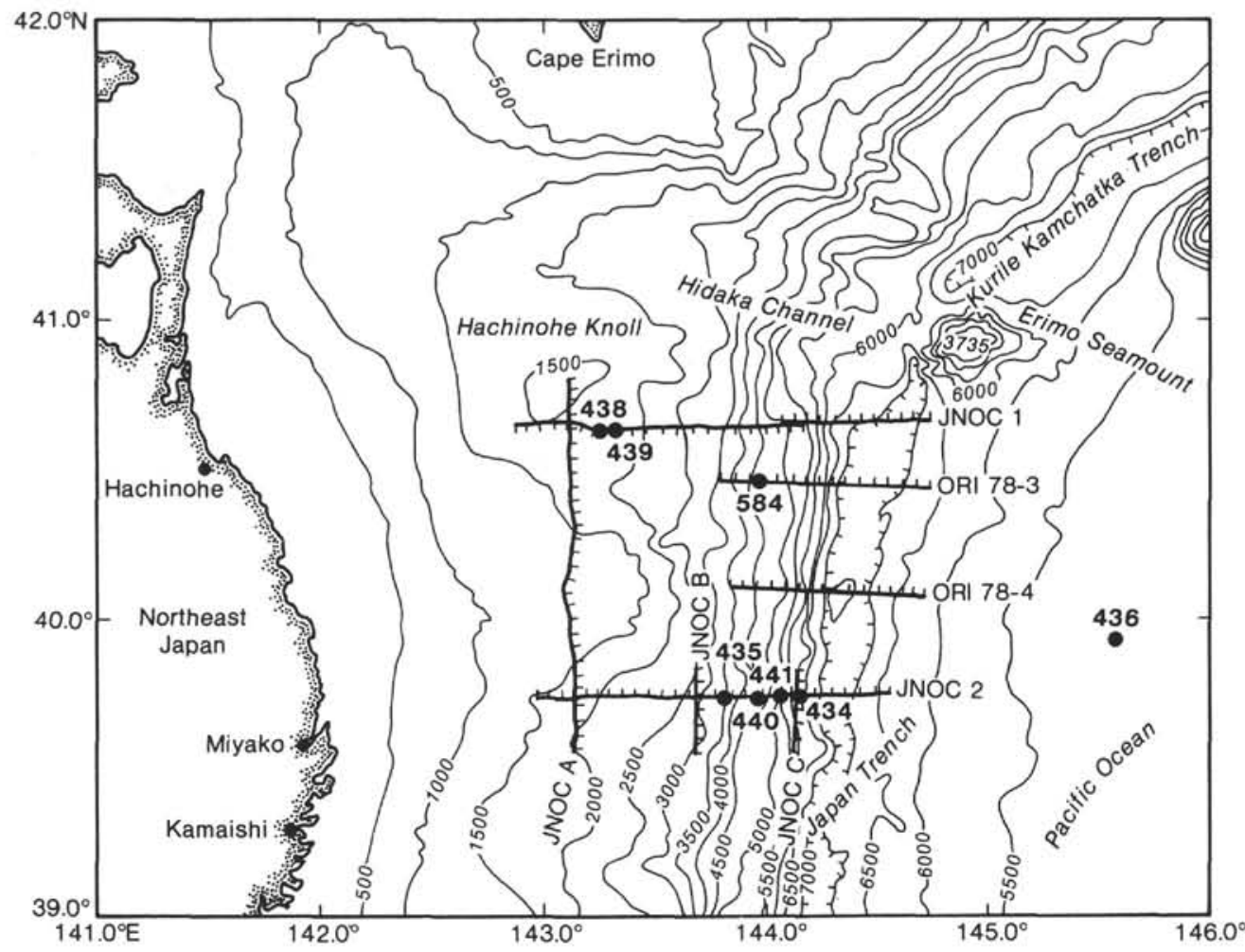

Figure 1. Location map of $\operatorname{Leg} 56,57$, and $87 \mathrm{~B}$ drill sites. Sites 434,435 , and 436 were drilled during Leg 56; Sites 438, 439, 440, and 441 during Leg 57; and Site 584 during Leg 87B. Submarine topography is shown together with multichannel seismic lines surveyed by JNOC and ORI. Note that only Site 436 is located on the Pacific Plate, and the others are on the Eurasian or North American Plate.
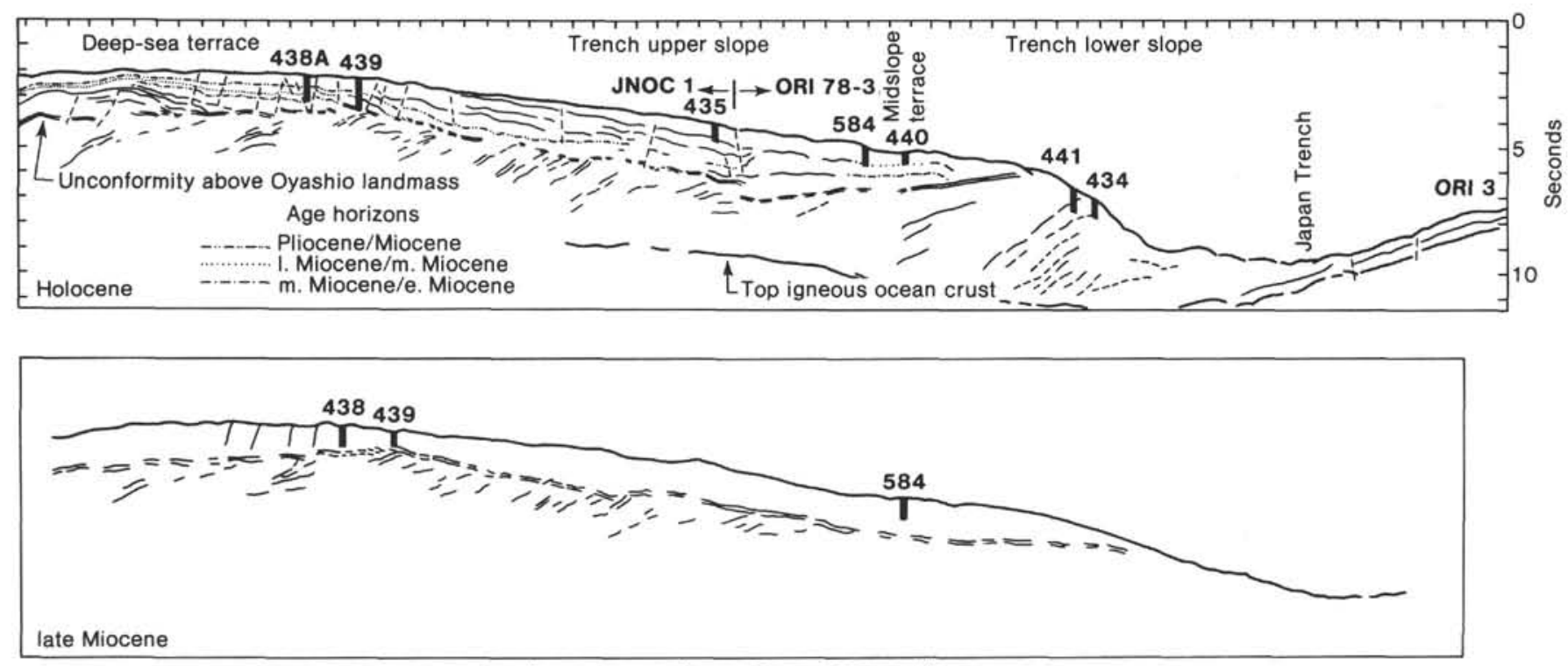

(composite profile JNOC $1+$ ORI 78-3)

Figure 2. Situation of drilling sites on the multichannel seismic lines, a composite of profiles JNOC 1 and ORI 78-3 (see Fig. 1 for location). Site 584 is located on the midslope of the landward side of the Japan Trench, a setting similar to that of Site 440 .

The occurrence pattern of the volcanic ash layers has a distinct peak around 3-2 Ma. There are no peaks in the Quaternary and upper Miocene (Figs. 6A and 6B). A frequency diagram was made for $\mathrm{L}$ and $\mathrm{P}$ types of volcanic ash layers. Type $\mathrm{D}$ is not taken into account be- cause it has a distribution concordant with the $\mathrm{L}$ and $\mathrm{P}$ types at Site 438 (Fujioka, this volume). Age was determined by diatom biostratigraphy and paleomagnetism (Akiba and Niitsuma, this volume), as well as by radiometric methods (Kaneoka, 1983). 

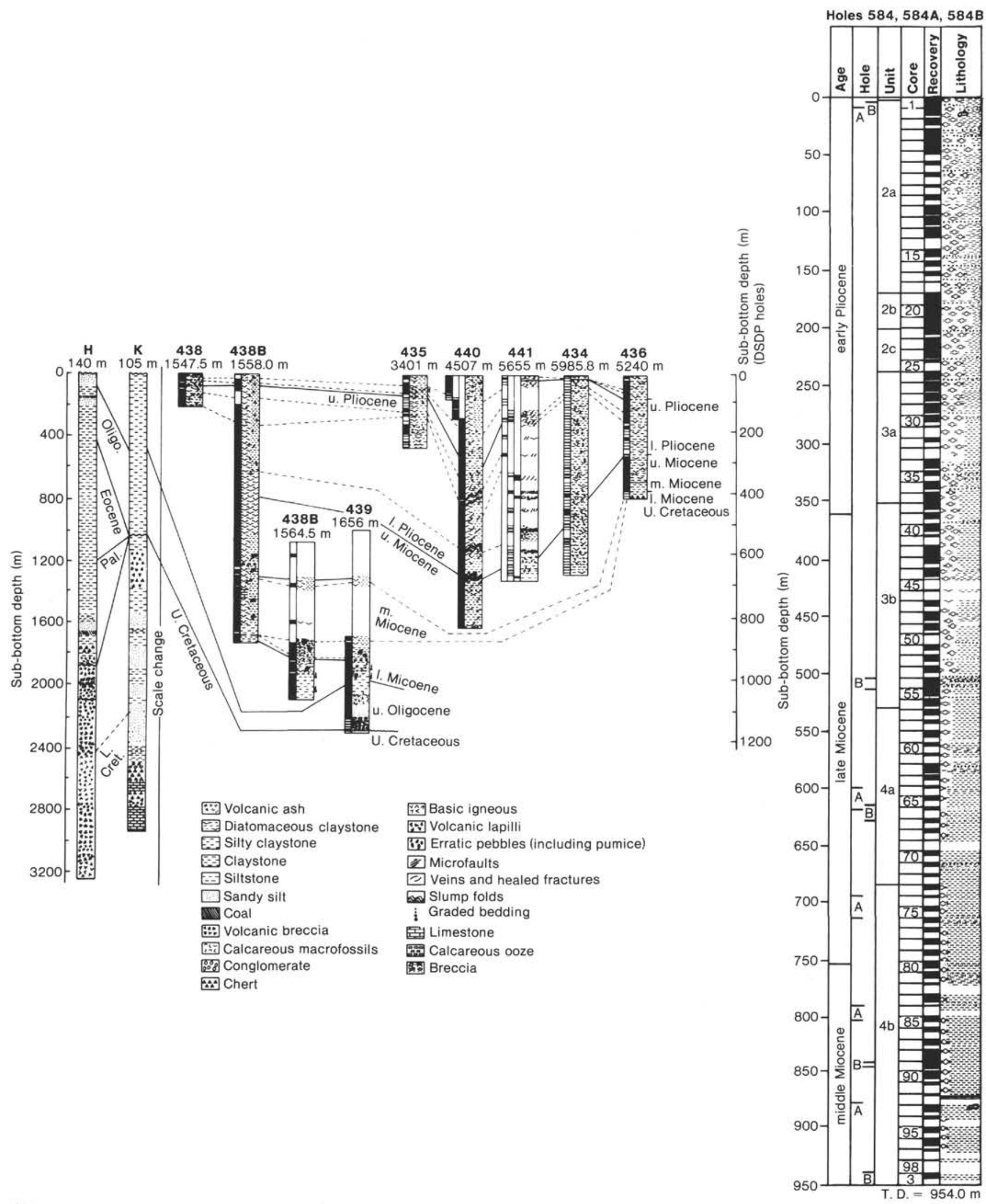

Figure 3. Lithologic columns of all drilling sites in the Japan Trench region during the IPOD program. Columns $\mathrm{H}$ and $\mathrm{K}$ are the drill holes by Teiseki Oil Company on the continental shelf off the northeastern Japan Arc (Tohoku Arc). T. D. = total depth. 


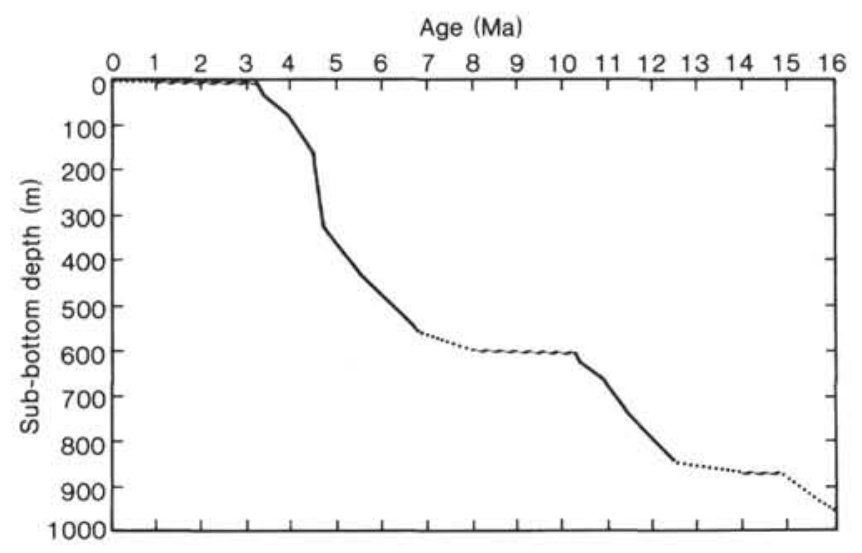

Figure 4. Sediment accumulation rate curve obtained by magnetobiostratigraphy of Site 584 .

\section{Chemical Composition of Volcanic Glass}

The $\mathrm{SiO}_{2}$ content of the volcanic glass ranges from 64 to $80 \%$ corresponding to compositions of dacite and rhyolite, respectively. The $\mathrm{Al}_{2} \mathrm{O}_{3}$ content varies from 10 to $15 \%$, the average is $11 \%$. The $\mathrm{FeO} / \mathrm{MgO}$ ratio is variable. These chemical compositions plot in a field on a $\mathrm{SiO}_{2}-\left(\mathrm{Na}_{2} \mathrm{O}+\mathrm{K}_{2} \mathrm{O}\right)$ diagram that belongs to the nonalkalic rock series and that in a FeO- $\left(\mathrm{Na}_{2} \mathrm{O}+\mathrm{K}_{2} \mathrm{O}\right)-\mathrm{MgO}$ diagram (AMF diagram) exhibits trends similar to those of a tholeiitic rock series (Fujioka et al., 1980; Fujioka, this volume).

\section{Neutron Activation Analysis: Hygromagmaphile Element Concentration}

As a complement to classic analytical methods, we considered the hygromagmaphile element content in volcanic glass shards from Legs 57 and 87B and compared the results for the Japan Trench with Nankai Trough data.

\section{METHODS}

The neutron activation method used was pure instrumental activation analysis (without chemical separation), using epithermal neutron irradiation (OSIRIS reactor in Saclay, France, Commissariat de l'Energie Atomique Groupe des Sciences de la Terre, Laboratoire Pierre Sud). Irradiation was performed under $\mathrm{Cd}$ vials, followed by several measurements made at different intervals from 8 days to 1 month after radiation (Chayla et al., 1973). The reference standard used is GNS (De la Roche and Govindaraju, 1976), and the sample standard used is BEN (Govindaraju, 1980; Table 3).

Hygromagmaphile elements (Th, Ta, La, Ce, Hf, $\mathrm{Zr}, \mathrm{U}, \mathrm{Rb}, \mathrm{Cs}$ ) defined by Treuil are characterized by a low solid/liquid partition coefficient. The content of such elements increases in magmatic liquid with differentiation of the magma. Highly hygromagmaphile elements in magmatic rock samples representative of liquid keep the same ratios as in the initial solid form. Consequently, highly hygromagmaphile elements issuing from the same homogeneous initial solid are linearly correlated, and the straight line issues from the origin (Joron and Treuil, 1977).

\section{Choice and Preparation of Samples}

Smear-slide samples were selected for their glass content and their low feldspar and clay content. All samples were cleaned with ultrasound to clear the clay from the glass shards. Roughly $120 \mathrm{mg}$ of glass were crushed and analyzed.

\section{RESULTS}

Apart from iron and sodium whose contents are expressed in percentages of $\mathrm{Fe}_{2} \mathrm{O}_{3}$ and $\mathrm{Na}_{2} \mathrm{O}$, other ele- mental contents are expressed in ppm (Table 2). Analytical accuracy is about $10 \%$ for $\mathrm{Zr}$ and $5 \%$ for other elements. The results for the BEN standard and for the data used for the reference GNS standard are listed in Table 3.

Some samples were contaminated with diatoms that could not be separated from the glass. Consequently, some results are underestimated, but the ratios between hygromagmaphile elements are not affected.

Two pairs of elements (Th and $\mathrm{U}, \mathrm{Th}$ and $\mathrm{Rb}$ ) are fairly well correlated (Fig. 7). Thus the samples have not undergone any important alteration ( $\mathrm{Rb}$ and $\mathrm{U}$ are affected by alteration, Joron et al., 1980; Joron and Treuil, 1977). The Th/Ta ratios are between 6 and 31 (Table 2). The values are noticeably higher than those found in calc-alkalic rock series on land, such as samples from the Fuji, the Ohmuroyama, and Asama volcanoes where $4<\mathrm{Th} / \mathrm{Ta}<12$ (Wood et al., 1980).

The analyzed glasses have high $\mathrm{La} / \mathrm{Tb}$ ratios (13 to 37). Contents of transition elements are low whereas those of hygromagmaphile elements are high, indicating that these glasses issued from a highly differentiated magmatic liquid.

$\mathrm{Th}$ is not correlated with either $\mathrm{La}, \mathrm{Tb}, \mathrm{Hf}$, or $\mathrm{Ta}$ (Fig. 8), rather the ratios spread into different groups, showing no relation between the content of hygromagmaphile elements and the sample age. Because we lack the most basic series, the rebuilding of the evolution of the series is difficult; however, the presence of these different groups shows that the analyzed glass does belong to a unique series.

\section{Comparison with Nankai Trough Data (Leg 87A)}

Quaternary samples from the Nankai Trough show, as in the Japan Trench, a high $\mathrm{Th} / \mathrm{Ta}$ ratio (11 to 17 , Table 4), characteristic of a subduction zone. The relations of $\mathrm{Th}$ with $\mathrm{Ta}$ and with $\mathrm{La}$ are represented in Figure 9, together with the Leg 57 (Sites 438, 439, and 440) and Leg 87 (Site 584) data. Glass coming from the south of Shikoku is more differentiated than that of eastern Honshu. They have a higher hygromagmaphile element content; the $\mathrm{La} / \mathrm{Tb}$ ratio varies from 24 to 45 south of Shikoku and from 17 to 37 for the samples east of Honshu. This higher differentiation may be linked with the more recent age of the Nankai Trough samples.

On the other hand, at least two different "evolutionary lines" can be distinguished in the variation diagrams: (1) a line gathering most of the samples from Leg 57 and Site 584 (Leg 87) and (2) a line with a few samples from Leg 57 and Site 584 (Leg 87), and all the samples from Sites 582 and 583 (Leg 87).

\section{DISCUSSION}

The history of the explosive volcanism compiled using the tephras from Site 584 shows a maximum around Pliocene and late Miocene times. This result is in good agreement with the results obtained at Site 438 (Cadet and Fujioka, 1980; Fujioka, 1983b; Fujioka, this volume). The Tohoku Arc is one of the most thoroughly studied island arcs in the world. The geology and tectonic evolution of this arc during the Tertiary have been compiled and discussed by many authors (Amano, 1983; 
Kitamura, 1959; Niitsuma, 1978), and the history of the volcanism of this island arc through the Tertiary has been equally well studied (Fujioka, 1983a, b; Sugimura et al., 1963; Ozawa, 1963; Horikoshi, 1975). According to these compilations, the explosive volcanism in this arc is divided into the following periods: an early Miocene, chiefly andesitic phase of volcanism (Huzioka, 1963; Fujioka, 1983a), and a middle Miocene phase of large-scale acidic volcanism related to the formation of the Kuroko deposits (Fujioka, 1983a; Kaneoka, 1983). After the late Miocene, volcanism became bimodal, andesitic in the western part of the Tohoku Arc, and simultaneously acidic in the eastern part (Konda, 1974; Konda and Ueda, 1980). In the Pliocene, large-scale acidic volcanism took place everywhere in relation to the gradual uplift of the Tohoku Arc (Huzioka, 1963; Fujioka, 1983a).

\section{CONCLUSIONS}

The volcanogenic sediments at Site 584 have a distinct maximum in frequency of volcanic ash from 6 to $3 \mathrm{Ma}$. The peak is in good agreement with the younger peak observed at Site 438, suggesting that during Pliocene times an episode of large-scale acidic volcanism took place onshore (Tohoku Arc) in relation to the uplift of the Tohoku Arc and to the intrusion of the Tertiary granites accompanied by the vein type ore deposits under the compressional stress field (Fujioka, 1983a).

The hygromagmaphile element analysis shows two lines of evolution that might be linked to at least two different sources and that are possibly related to the diverse subduction context of the Japan and Nankai Trench areas. Some of the most differentiated glass sampled east of Honshu has the same geochemical characteristics as ash from south of Shikoku. This glass may have issued from magma linked to the Philippine Plate subduction and was than transported northward.

\section{ACKNOWLEDGMENTS}

The authors would like to express their sincere thanks to Drs. Kazuo Kobayashi and Yujiro Ogawa for their critical reading of the manuscript. Thanks are also due to Drs. K. Nakamura, T. Furuta, and A. Pouclet and to Mr. K. Koga and Ms. A. M. Dubois for their technical help.

\section{REFERENCES}

Amano, K., 1983. Miocene geology of Seki district, Miyagi prefecture, northeast Japan-block faulting in Miocene. J. Geol. Soc. Jpn., 89:41-53.

Cadet, J. P., and Fujioka, K., 1980. Neogene volcanic ashes and explosive volcanism: Japan Trench transect, Leg 57, Deep Sea Drilling Project. In Scientific Party, Init. Repts. DSDP, 56, 57, Pt. 2: Washington (U.S. Govt. Printing Office), 1027-1041.

Chayla, B., Jafrezic, H. and Joron, J. L., 1973. Analyse par activation dans les neutrons épithermiques. Application à la détermination d'éléments en trace dans les roches. C. R. Seances Acad. Sci., 77:273-275.
De la Roche, H., and Govindaraju, K., 1976 . Nouveaux étalons géochimiques granite GS.N et feldspath FK.N, Analusis 4(8):347-372.

Fujioka, K., 1983a. Where were the "Kuroko deposits" formed-looking for the present day analogy. Min. Geol., Spec. Issue, 11:55-68. 1983b. History of the explosive volcanism of the Tohoku Arc from the core sediment samples of the Japan Trench. J. Volcanol. Soc. Jpn., 28:41-58.

Fujioka, K., Furuta, T., and Arai, F., 1980. Petrography and geochemistry of volcanic glass: Leg 57, Deep Sea Drilling Project. In Scientific Party, Init. Repts. DSDP, 56, 57, Pt. 2: Washington (U.S. Govt. Printing Office), 1049-1066.

Govindaraju, K., 1980. Report on three GIT-IWG rock reference samples: Anorthosite from Greenland AN.G.; Basalte d'Essay la Côte BE.N.; Granite de Beauvoir MA.N. Geostandards Newsl., IV(1): 49-138.

Horikoshi, E., 1975. Genesis of Kuroko-stage deposits from the tectonic point of view. J. Volcanol. Soc. Jpn., 20:341-353.

Huzioka, K., 1963. Geology of the Green Tuff region in Japan. Min. Geol., 13:358-375.

Joron, J.-L., Bollinger, C., Quisefit, J. P., Bougault, H., and Treuil, M., 1980. Trace elements in Cretaceous basalts at $25^{\circ} \mathrm{N}$ in the Atlantic Ocean: alteration, Mantel composition, and magmatic processes. In Donnelly, J., Francheteau, J., Bryan, W., Robinson, P., Flower, M., Salisbury, M., et al., Init. Repts. DSDP, 51, 52, 53, Pt. 2: Washington (U.S. Govt. Printing Office), 1087-1098.

Joron, J.-L., and Treuil, M., 1977. Utilisation des propriétés des (éléments fortement hygromagmaphiles pour l'étude de la composition chimique et de l'hétérogénéité du manteau. Bull. Soc. Geol. Fr., 6(XIX):1197-1205.

Kaneoka, I., 1983. On the radiometric ages of volcanic rocks from the northern part of the Honshu Island. Min. Geol., Spec. Issue, 11: 69-78.

Kitamura, N., 1959. Tertiary orogenesis in northern Honshu, Japan. Sci. Rep., Tohoku Univ., Ser. 3, 49:1-98.

Konda, T., 1974. Bimodal volcanism in the northeast Japan arc. $J$. Geol. Soc. Jpn., 80:81-89.

Konda, T., and Ueda, Y., 1980. K-Ar age of the Tertiary volcanic rocks in the Tohoku area, Japan. J. Jpn. Assoc. Mineral. Petrol. Econ. Geol., Spec. Issue, 2:343-346.

Niitsuma, N., 1978. Magnetic stratigraphy of the Japanese Neogene and the development of the island arcs of Japan. J. Phys. Earth, 26(suppl.):S367-S378.

Ozawa, A., 1963. Neogene orogenesis, igneous activity and mineralization in the central part of northeast Honshu. (1) On the Neogene igneous activity. J. Jpn. Assoc. Mineral. Petrol. Econ. Geol., 50:167-184.

Shipboard Scientific Party, 1983. Leg 87 drills off Honshu and SW Japan. Geotimes, 28(1):15-18.

Sugimura, A., Matsuda, T., Chinzei, K., and Nakamura, K., 1963. Quantitative distribution of late Cenozoic volcanic materials in Japan. Bull. Volcanol., 26:125-140.

von Huene, R., Langseth, M., Nasu, N., and Okada, H., 1980. Summary, Japan Trench transect. In Scientific Party, Init. Repts. DSDP, 56, 57, Pt. 1.: Washington (U.S. Govt. Printing Office), 473-488.

Wood, D. A., Joron, J.-L., Marsh, N. G., Tarney, J., and Treuil, M., 1980. Major and trace-element variations in basalts from the North Philippine Sea drilled during Deep Sea Drilling Project Leg 58: a comparative study of back-arc-basin basalts with lava series from Japan and mid-ocean ridges. In Klein, G. deV., Kobayashi, K., et al., Init. Repts. DSDP, 58: Washington (U.S. Govt. Printing Office), 873-894.

Date of Initial Receipt: 11 July 1984

Date of Acceptance: 5 March 1985 


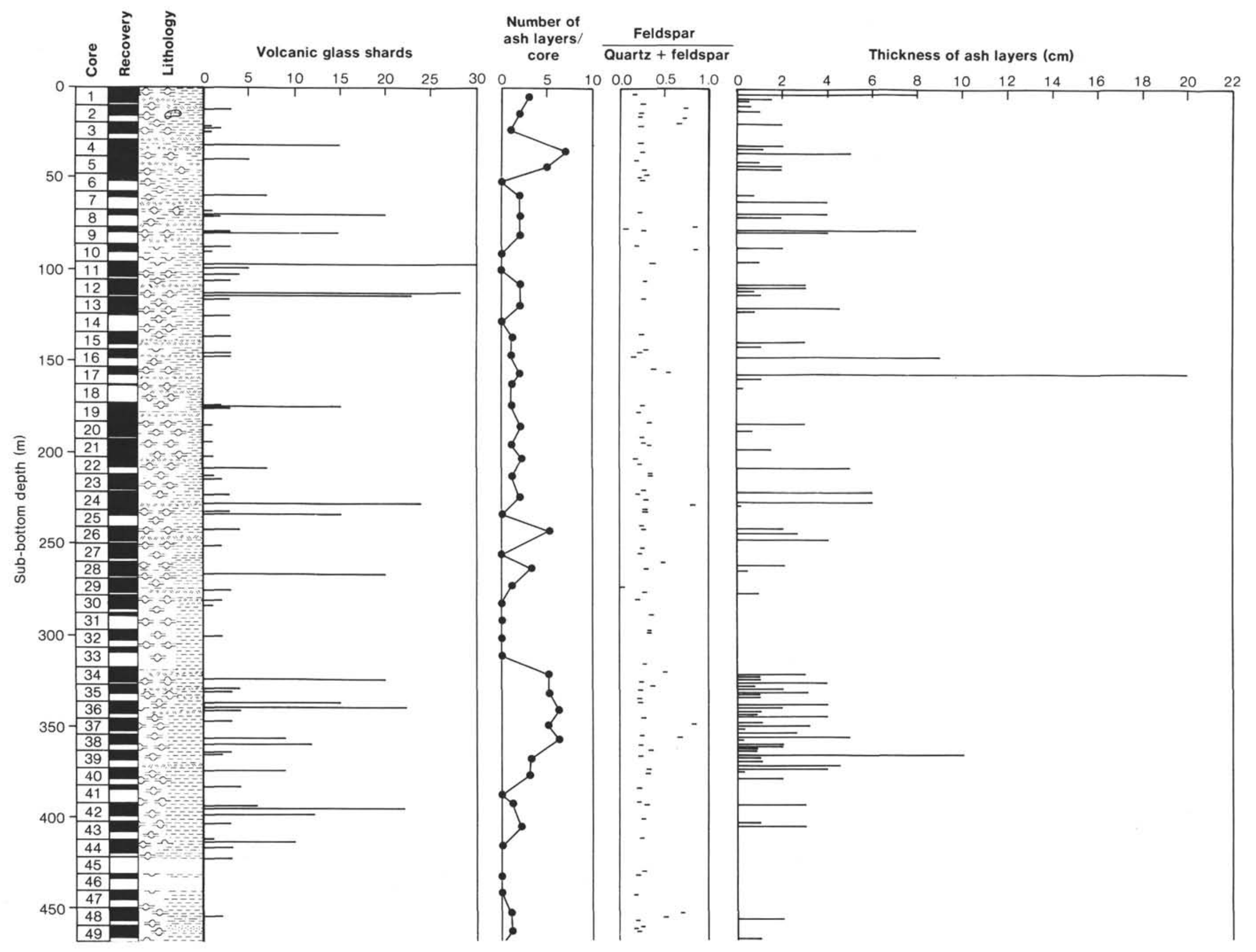



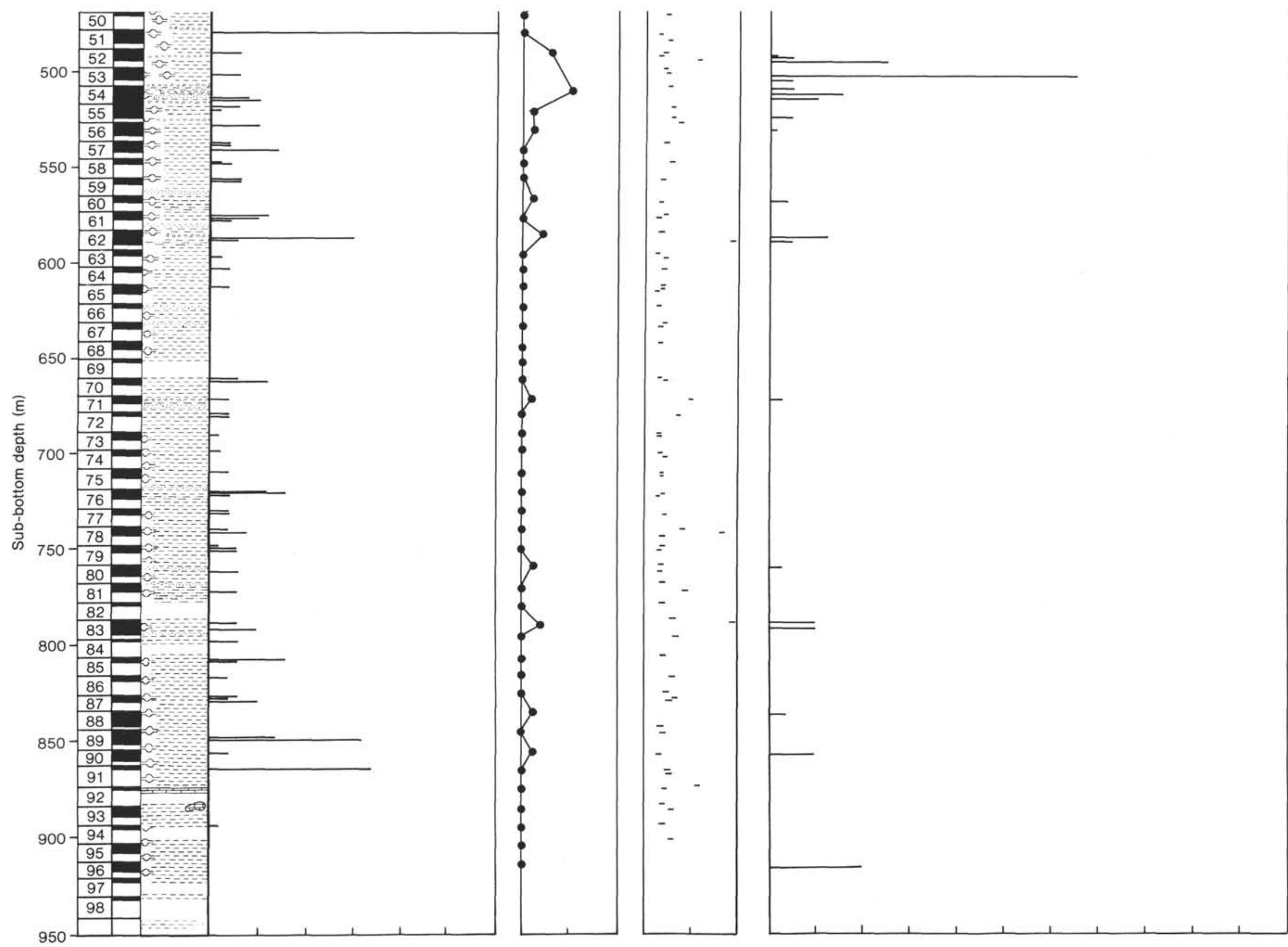
Table 1. Composition of volcanic ash layers, smear-slide data, Site 584.

\begin{tabular}{|c|c|c|c|c|c|c|c|c|c|c|c|c|c|c|c|c|c|c|c|c|c|c|c|c|c|c|c|c|c|c|c|c|c|c|c|c|}
\hline \multirow[b]{2}{*}{ Component } & \multicolumn{36}{|c|}{ Sample (Hole 584) } \\
\hline & $\begin{array}{l}1.1 \\
145\end{array}$ & $\begin{array}{c}4-1 \\
2\end{array}$ & $\begin{array}{c}4-1 \\
2\end{array}$ & $\begin{array}{l}4-1 \\
115\end{array}$ & $\begin{array}{l}5.2 \\
15\end{array}$ & $\begin{array}{l}7.2 \\
103\end{array}$ & $\begin{array}{l}8.2 \\
56\end{array}$ & $\begin{array}{l}8.2 \\
59\end{array}$ & $\begin{array}{l}9-1 \\
65\end{array}$ & $\begin{array}{l}9-2 \\
40\end{array}$ & $\begin{array}{l}10-2 \\
118\end{array}$ & $\begin{array}{c}11-1 \\
96\end{array}$ & $\begin{array}{c}12.3 \\
28\end{array}$ & $\begin{array}{c}12-3 \\
41\end{array}$ & $\begin{array}{l}12-3 \\
128\end{array}$ & $\begin{array}{c}12-5 \\
14\end{array}$ & $\begin{array}{l}13.2 \\
104\end{array}$ & $\begin{array}{l}13-3 \\
100\end{array}$ & $\begin{array}{l}15-3 \\
110\end{array}$ & $\begin{array}{l}16-2 \\
130\end{array}$ & $\begin{array}{l}17-3 \\
40\end{array}$ & $17, \mathrm{CC}$ & $\begin{array}{c}19-1 \\
37\end{array}$ & $\begin{array}{c}20-2 \\
95\end{array}$ & $\begin{array}{c}20-6 \\
34\end{array}$ & $\begin{array}{c}21-3 \\
16\end{array}$ & $\begin{array}{l}22.3 \\
128\end{array}$ & $\begin{array}{l}23-6 \\
125\end{array}$ & $\begin{array}{c}24.4 \\
19\end{array}$ & $\begin{array}{c}24.4 \\
49\end{array}$ & $\begin{array}{c}24.4 \\
99\end{array}$ & $\underset{3}{25.2}$ & $\begin{array}{l}26-1 \\
139\end{array}$ & ${ }_{37}^{26-4}$ & $\begin{array}{c}27 \cdot 2 \\
27\end{array}$ & $\begin{array}{l}28-5 \\
102\end{array}$ \\
\hline and & 25 & so & 35 & 45 & 55 & 15 & 40 & 22 & 10 & 30 & 25 & 9 & 23 & s & 27 & 14 & 8 & 25 & 5 & 25 & 55 & 20 & 20 & 25 & 25 & 25 & 20 & - & 10 & 32 & 10 & 45 & 8 & 5 & 65 & 5 \\
\hline & 52 & 40 & 30 & 25 & 30 & 40 & 40 & 45 & so & 40 & ss & 31 & 47 & 60 & 27 & 36 & 60 & 4 & 85 & so & 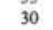 & 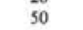 & 0 & 6 & s. & 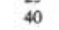 & 0 & 90 & 75 & 48 & 40 & 30 & 77 & 70 & 30 & 5 \\
\hline Clay & 23 & 10 & 35 & 30 & 15 & 45 & 20 & 33 & 40 & 30 & 20 & 40 & 30 & 35 & ${ }_{30}^{30}$ & 50 & 32 & 30 & 10 & 25 & is & 30 & 30 & 10 & 10 & 35 & 20 & 10 & 15 & 20 & 25 & 25 & 15 & 25 & 5 & 90 \\
\hline $\begin{array}{l}\text { Quartz } \\
\text { Feldspar }\end{array}$ & 35 & $\begin{array}{l}25 \\
12\end{array}$ & 18 & $\begin{array}{l}32 \\
10\end{array}$ & 15 & $\begin{array}{l}15 \\
8\end{array}$ & $\begin{array}{l}28 \\
12\end{array}$ & $\begin{array}{l}4 \\
5\end{array}$ & $\begin{array}{l}4 \\
5\end{array}$ & 15 & 8 & 15 & $\begin{array}{l}12 \\
16\end{array}$ & $\begin{array}{l}10 \\
8\end{array}$ & $?$ & 2 & 8 & 4 & 12 & 9 & $\begin{array}{l}15 \\
15\end{array}$ & ${ }_{14}^{9}$ & 8 & ${ }_{6}^{11}$ & $\begin{array}{l}8 \\
4\end{array}$ & ${ }_{4}^{5}$ & ${ }_{3}^{4}$ & ${ }_{7}^{4}$ & $\begin{array}{l}5 \\
4\end{array}$ & ${ }_{3}^{3}$ & $\begin{array}{l}8 \\
4\end{array}$ & $\begin{array}{l}12 \\
14\end{array}$ & $\begin{array}{l}3 \\
4\end{array}$ & $\frac{7}{4}$ & 8 & $\begin{aligned} 12 \\
8\end{aligned}$ \\
\hline $\begin{array}{l}\text { Feldspar } \\
\text { Mica }\end{array}$ & 5 & $\begin{array}{r}12 \\
7\end{array}$ & 18 & 10 & 7 & 8 & 12 & 5 & 5 & 6 & 7 & 13 & 16 & 8 & 5 & 6 & 5 & 3 & 9 & 4 & 15 & 14 & 5 & 6 & 4 & 4 & 3 & 7 & 4 & 3 & 4 & 14 & 4 & 4 & 7 & 8 \\
\hline $\begin{array}{l}\text { Heavy minerals } \\
\text { Clay }\end{array}$ & 10 & $\begin{array}{l}8 \\
5\end{array}$ & $\begin{array}{l}21 \\
\text { tr. }\end{array}$ & 7 & 8 & $\begin{array}{r}3 \\
17\end{array}$ & ${ }_{20}^{7}$ & ${ }_{24}^{t r}$ & 28 & 30 & $\begin{array}{l}\mathrm{tr} \\
12\end{array}$ & 23 & 18 & 20 & ${ }_{28}^{\text {tr. }}$ & 43 & 28 & 15 & & ${ }_{24}^{2}$ & 5 & ${ }_{29}^{1}$ & 46 & 8 & 7 & $\begin{array}{c}1 \\
16\end{array}$ & $\begin{array}{l}1 \\
4\end{array}$ & & $\begin{array}{ll}\pi . \\
12\end{array}$ & 20 & 23 & 22 & $\begin{array}{l}\text { tr. } \\
12\end{array}$ & $\begin{array}{c}1 \\
20\end{array}$ & ${ }_{3}^{t .}$ & 27 \\
\hline $\begin{array}{l}\text { Lithic fragments } \\
\text { Volcanic ash } \\
\text { Palagonite }\end{array}$ & 35 & 15 & 39 & 40 & 45 & 40 & 20 & 4 & $\begin{array}{r}3 \\
3 \\
51 \\
1\end{array}$ & 21 & 58 & $\begin{array}{l}30 \\
\text { tr. }\end{array}$ & 36 & 40 & 28 & $\begin{array}{c}2 \\
22 \\
1\end{array}$ & 36 & $\begin{array}{l}1 \\
51 \\
\text { ti. }\end{array}$ & 43 & si & $\begin{array}{c}54 \\
1\end{array}$ & 38 & $\begin{array}{l}1 \\
15\end{array}$ & 66 & $\begin{array}{c}1 \\
34 \\
1\end{array}$ & 35 & 83 & $\begin{array}{c}81 \\
1\end{array}$ & $\begin{array}{r}56 \\
9\end{array}$ & 35 & $\begin{array}{c}23 \\
1\end{array}$ & $\begin{array}{r}10 \\
14 \\
1\end{array}$ & $\begin{array}{l}\text { tr. } \\
65 \\
1\end{array}$ & ${ }_{\mathrm{si}}^{\mathrm{tr}}$ & i & ${ }_{20}^{5}$ \\
\hline $\begin{array}{l}\text { Glauconite } \\
\text { Pyrite } \\
\text { Carbonate } \\
\text { Foraminifers }\end{array}$ & 3 & 8 & is & ${ }^{8}$ & $\begin{array}{l}25 \\
\text { tr. }\end{array}$ & 11 & 9 & 4 & 7 & 3 & 9 & 5 & $\begin{array}{l}1 \\
4\end{array}$ & 3 & $\begin{array}{l}1 \\
4\end{array}$ & $\begin{array}{l}3 \\
1\end{array}$ & $\begin{array}{l}4 \\
1\end{array}$ & 3 & ${ }^{6}$ & 1 & ${ }_{2}^{3}$ & 2 & 1 & i & $i$ & 1 & & & $i_{1}^{2}$ & $\begin{array}{l}5 \\
1 \\
2\end{array}$ & $\begin{array}{l}1 \\
6 \\
1 \\
1\end{array}$ & $\begin{array}{l}1 \\
4 \\
1\end{array}$ & $i$ & 4 & to. & $\begin{array}{l}6 \\
5\end{array}$ \\
\hline $\begin{array}{l}\text { Forannofiess } \\
\text { Danatoossils } \\
\text { Diatoms }\end{array}$ & 12 & 15 & 5 & th. & th. & 4 & 1 & 12 & 3 & 18 & 4 & 10 & 8 & 12 & 22 & 13 & ${ }_{12}^{t r}$ & $\begin{array}{l}\text { tr. } \\
18\end{array}$ & 13 & 8 & s & 6 & 18 & 6 & 2 & 27 & 3 & 5 & 10 & 22 & $\begin{array}{c}1 \\
23\end{array}$ & 8 & 17 & 8 & 2 & 10 \\
\hline $\begin{array}{l}\text { Radiolarians } \\
\text { Sponge } \\
\text { Plant }\end{array}$ & & 5 & 2 & 3 & & 2 & 3 & 6 & 1 & ${ }_{4}^{\text {tr. }}$ & 2 & 3 & $\begin{array}{l}1 \\
4\end{array}$ & 7 & this & 4 & 4 & $\begin{array}{l}4 \\
1\end{array}$ & $\stackrel{8}{9}_{9}$ & 1 & tr. & 1 & 6 & 1 & 1 & 7 & 1 & 2 & $\begin{array}{l}1 \\
8\end{array}$ & 8 & 7 & $\begin{array}{c}t . \\
4 \\
\text { tr. }\end{array}$ & 4 & 4 & 1 & $\begin{array}{l}3 \\
4\end{array}$ \\
\hline $\begin{array}{l}\text { Others } \\
\text { Ont }\end{array}$ & & & & & & & & & & & & 1 & & & & & & $\mathrm{i}$ & & & & & & & & 1 & & & & 1 & 1 & & & & & \\
\hline
\end{tabular}

Table 1. (Continued).

\begin{tabular}{|c|c|c|c|c|c|c|c|c|c|c|c|c|c|c|c|c|c|c|c|c|c|c|c|c|c|c|c|c|c|c|c|c|c|c|}
\hline \multirow[b]{2}{*}{ Component } & \multicolumn{32}{|c|}{ Sample (Hole 584) } & \multicolumn{2}{|c|}{$\begin{array}{l}\text { Sample } \\
\text { (Hole } \\
\text { S84A) }\end{array}$} \\
\hline & $\begin{array}{c}34.4 \\
72\end{array}$ & $\begin{array}{c}34-4 \\
12\end{array}$ & $\begin{array}{l}34 \cdot 6 \\
22\end{array}$ & $\begin{array}{c}35-1 \\
25\end{array}$ & $\begin{array}{c}35-2 \\
56\end{array}$ & $\begin{array}{c}36-1 \\
62\end{array}$ & $\begin{array}{c}36-2 \\
30\end{array}$ & $\begin{array}{c}37-4 \\
18\end{array}$ & $\begin{array}{c}38-1 \\
41\end{array}$ & $\begin{array}{c}39-2 \\
9\end{array}$ & $\begin{array}{l}40-1 \\
45\end{array}$ & $\begin{array}{l}43-1 \\
28\end{array}$ & $\begin{array}{c}49-3 \\
12\end{array}$ & $\begin{array}{l}50-1 \\
93\end{array}$ & $\begin{array}{c}51.2 \\
138\end{array}$ & $\begin{array}{c}54-1 \\
81\end{array}$ & $\begin{array}{l}55.3 \\
138\end{array}$ & $\begin{array}{l}55.5 \\
120\end{array}$ & $\begin{array}{l}56-1 \\
40\end{array}$ & $\begin{array}{c}62-1 \\
79\end{array}$ & $\begin{array}{c}62-3 \\
60\end{array}$ & $\begin{array}{c}62-3 \\
75\end{array}$ & $\begin{array}{l}71-1 \\
125\end{array}$ & $\begin{array}{c}78-2 \\
22\end{array}$ & $\begin{array}{l}80-1 \\
131\end{array}$ & $\begin{array}{l}83.2 \\
50\end{array}$ & $\begin{array}{l}88-1 \\
140\end{array}$ & $\begin{array}{l}89.3 \\
147\end{array}$ & $\begin{array}{l}90-1 \\
102\end{array}$ & $\begin{array}{c}91-1 \\
19\end{array}$ & $\begin{array}{c}95.1 \\
20\end{array}$ & $\begin{array}{l}96-2 \\
43\end{array}$ & $\begin{array}{l}2-2 \\
62\end{array}$ & $\begin{array}{l}2-2 \\
64\end{array}$ \\
\hline $\begin{array}{l}\text { Sand } \\
\text { Sint }\end{array}$ & s & 35 & 10 & 5 & 35 & 25 & 15 & 3 & 25 & 10 & 45 & 2 & 42 & 42 & 82 & 35 & 30 & 45 & 10 & 62 & 90 & 30 & 10 & 55 & 70 & 45 & 35 & 15 & 20 & 20 & 12 & 20 & 7 & 10 \\
\hline $\begin{array}{l}\text { Sitt } \\
\text { Clay }\end{array}$ & $\begin{array}{l}85 \\
10\end{array}$ & $\begin{array}{l}35 \\
30\end{array}$ & $\begin{array}{l}30 \\
60\end{array}$ & $\begin{array}{l}80 \\
15\end{array}$ & $\begin{array}{l}100 \\
55\end{array}$ & $\begin{array}{l}55 \\
20\end{array}$ & $\begin{array}{l}52 \\
33\end{array}$ & $\begin{array}{l}38 \\
59\end{array}$ & 70 & $\begin{array}{l}75 \\
15\end{array}$ & $\begin{array}{l}45 \\
10\end{array}$ & $\begin{array}{l}60 \\
38\end{array}$ & $\begin{array}{l}35 \\
23\end{array}$ & $\begin{array}{l}32 \\
26\end{array}$ & $\begin{array}{r}8 \\
10\end{array}$ & $\begin{array}{l}40 \\
25\end{array}$ & 45 & 45 & 80 & 15 & 5 & $\overline{70}$ & 70 & 15 & 15 & 55 & 45 & 35 & 50 & 50 & 38 & 50 & 43 & 80 \\
\hline Quartz & 6 & is & is & is & 11 & is & 8 & 12 & 4 & s & 6 & $\begin{array}{r}38 \\
6\end{array}$ & 22 & $\begin{array}{l}20 \\
12\end{array}$ & $\begin{array}{l}10 \\
15\end{array}$ & $\begin{array}{l}25 \\
12\end{array}$ & $\begin{array}{l}25 \\
10\end{array}$ & $\begin{array}{l}10 \\
10\end{array}$ & $\begin{array}{r}10 \\
6\end{array}$ & $\begin{array}{r}23 \\
8\end{array}$ & $\begin{array}{l}5 \\
5\end{array}$ & $\begin{array}{l}70 \\
15\end{array}$ & $\begin{array}{r}20 \\
3\end{array}$ & $\begin{array}{l}30 \\
15\end{array}$ & $\begin{array}{l}15 \\
12\end{array}$ & $\overline{10}$ & $\begin{array}{r}20 \\
5\end{array}$ & $\begin{array}{l}50 \\
12\end{array}$ & $\begin{array}{l}30 \\
10\end{array}$ & $\begin{array}{r}30 \\
7\end{array}$ & 7 & $\begin{array}{c}30 \\
7\end{array}$ & $\begin{array}{r}50 \\
6\end{array}$ & $\begin{array}{r}10 \\
5\end{array}$ \\
\hline $\begin{array}{l}\text { Feldspar } \\
\text { Mica }\end{array}$ & 5 & 10 & 10 & 10 & 10 & 10 & 8 & 15 & 4 & 4 & 5 & 6 & 5 & $\begin{array}{r}15 \\
2\end{array}$ & 20 & 8 & 8 & 12 & 4 & 10 & & & 4 & 20 & 12 & 14 & 15 & 7 & 8 & s & 4 & 2 & 3 & 3 \\
\hline $\begin{array}{l}\text { Heavy minerals } \\
\text { Clay }\end{array}$ & ${ }_{5}^{2}$ & & ${ }_{15}^{2}$ & $\begin{array}{c}1 \\
15\end{array}$ & 2 & 2 & & & 5 & & 1 & 28 & 2 & 18 & 2 & 1 & tr. & 2 & & 2 & 3 & 5 & 1 & & & 1 & & & 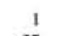 & 1 & & & & \\
\hline $\begin{array}{l}\text { lay } \\
\text { Lithic fragments }\end{array}$ & 5 & 14 & 15 & & 2 & 11 & 18 & 10 & & 15 & 8 & & 10 & & $\begin{array}{c}10 \\
5\end{array}$ & $\begin{array}{r}18 \\
6\end{array}$ & $\begin{array}{r}18 \\
6\end{array}$ & $\begin{array}{l}10 \\
8\end{array}$ & 10 & 7 & 7 & 37 & ${ }_{5}^{8}$ & 10 & 23 & 2 & & 47 & 27 & 28 & 48 & ${ }_{1}^{10}$ & $\begin{array}{l}30 \\
1\end{array}$ & 7 \\
\hline $\begin{array}{l}\text { Volcanic ash } \\
\text { Palagonite } \\
\text { Glauconite }\end{array}$ & 77 & 20 & $\begin{array}{r}30 \\
3\end{array}$ & $\begin{array}{c}s_{0} \\
1\end{array}$ & 55 & $\begin{array}{l}15 \\
1\end{array}$ & 32 & 46 & $\begin{array}{r}76 \\
1\end{array}$ & 57 & $\begin{array}{r}74 \\
1\end{array}$ & $\begin{array}{r}41 \\
1\end{array}$ & $\begin{array}{l}41 \\
12\end{array}$ & so & 30 & $\begin{array}{r}45 \\
1 \\
1\end{array}$ & $\begin{array}{r}32 \\
1 \\
1\end{array}$ & $\begin{array}{r}42 \\
2\end{array}$ & 71 & 52 & 80 & 15 & $\begin{array}{r}74 \\
1\end{array}$ & ${ }^{42}$ & 49 & 62 & $\begin{array}{l}61 \\
\text { t. } \\
3\end{array}$ & 16 & $\begin{array}{r}36 \\
2 \\
3\end{array}$ & 17 & $\begin{array}{l}15 \\
1 \\
15\end{array}$ & $\begin{array}{r}73 \\
2\end{array}$ & 46 & 77 \\
\hline $\begin{array}{l}\text { Pyrite } \\
\text { Carbonate } \\
\text { Foraminifers }\end{array}$ & & 4 & 2 & $i_{1}^{2}$ & 10 & $\begin{array}{l}5 \\
3\end{array}$ & 5 & $\begin{array}{l}6 \\
4\end{array}$ & $\begin{array}{l}3 \\
4\end{array}$ & ${ }_{1}^{2}$ & $\begin{array}{l}1 \\
4\end{array}$ & $\begin{array}{l}5 \\
2\end{array}$ & $\begin{array}{l}4 \\
4\end{array}$ & 3 & $s$ & $\begin{array}{l}4 \\
2\end{array}$ & $\begin{array}{l}3 \\
1\end{array}$ & 10 & $\begin{array}{l}3 \\
1\end{array}$ & 6 & 4 & 3 & 3 & $s$ & 7 & "1 & 12 & $\begin{array}{l}3 \\
2\end{array}$ & 4 & $\begin{array}{l}10 \\
18\end{array}$ & $\begin{array}{c}10 \\
1\end{array}$ & $\begin{array}{c}1 \\
\text { tr. }\end{array}$ & $\begin{array}{l}4 \\
2\end{array}$ & $\begin{array}{l}4 \\
1\end{array}$ \\
\hline $\begin{array}{l}\text { Nannofossils } \\
\text { Diatoms }\end{array}$ & & & & & 2 & 1 & & & & & & & & & & & & & 2 & & & & & . & & & & & & & & & & \\
\hline $\begin{array}{l}\text { Diatoms } \\
\text { Radiolarians }\end{array}$ & 4 & $\begin{array}{r}30 \\
2\end{array}$ & $\begin{array}{l}15 \\
\text { tr. }\end{array}$ & 5 & & 13 & 19 & 5 & 3 & 10 & & 7 & & & 10 & & $\begin{array}{l}15 \\
\text { tr. }\end{array}$ & 1 & 2 & 12 & 1 & 15 & 1 & 2 & 6 & & 3 & 10 & 6 & 8 & 9 & 1 & ${ }_{t r}^{5}$ & ${ }_{t 5}^{2}$ \\
\hline $\begin{array}{l}\text { Sponge } \\
\text { Plant }\end{array}$ & 1 & 5 & 8 & 1 & & 7 & 5 & 2 & & 6 & & 4 & & & 3 & 2 & 3 & 3 & 1 & 3 & & 10 & tr. & & 3 & & 1 & 1 & 3 & 3 & 3 & 3 & 2 & $i$ \\
\hline Others & & & & & & & & & & & & & & & & & 2 & & & & & & & & & & & $\stackrel{2}{\stackrel{2}{\text { (pumice) }}}$ & & & $\stackrel{2}{2}$ & & & \\
\hline
\end{tabular}

Note: Sample numbers are expressed in Core-Section (depth in section in $\mathrm{cm}$ ). Upper three rows show the volume percentages of the grain size of the materials in the volcanic ash layers. tr. $=$ trace. 
Table 2. Instrumental neutron activation analysis of samples from Leg 87 (Site 584) and Leg 57 (Sites 438-440).

\begin{tabular}{|c|c|c|c|c|c|c|c|c|c|c|c|c|c|c|c|c|c|c|c|c|c|}
\hline Sample & $\begin{array}{l}\text { Number } \\
\text { in Figs. } \\
7 \text { and } 8\end{array}$ & Age & $\mathrm{Fe}_{2} \mathrm{O}_{3}$ & $\mathrm{Na}_{2} \mathrm{O}$ & $\mathrm{Sc}$ & Co & $\mathrm{Ni}$ & $\mathrm{Rb}$ & $\mathrm{Zr}$ & $\mathrm{Sb}$ & Cs & $\mathrm{Ba}$ & La & Eu & $\mathrm{Tb}$ & $\mathrm{Hf}$ & $\mathrm{Ta}$ & Th & U & $\mathrm{Th} / \mathrm{Ta}$ & $\mathrm{La} / \mathrm{Tb}$ \\
\hline \multicolumn{22}{|l|}{ Leg 57} \\
\hline $438 \mathrm{~A}-2-5,20$ & 1 & Pleistocene & 2.12 & 3.9 & 7.7 & 2.8 & 7 & 67 & 165 & 0.72 & 3.5 & 692 & 15.0 & 0.85 & 0.53 & 4.5 & 0.25 & 7.7 & 2.5 & 31 & 28 \\
\hline $440 \mathrm{~B}-3-1,32$ & 2 & Pleistocene & 2.31 & 3.8 & 8.7 & 3.7 & 11 & 42 & 148 & 0.45 & 1.8 & 479 & 16.0 & 0.95 & 0.77 & 4.4 & 0.45 & 4.8 & 1.5 & 11 & 21 \\
\hline 440 B- $-34-2,27$ & 3 & upper Pliocene & 2.02 & 3.6 & 9.2 & 1.1 & 2 & 31 & 133 & 0.87 & 1.1 & 434 & 13.1 & 1.25 & 0.84 & 4.2 & 0.48 & 3.3 & 1.1 & 7 & 16 \\
\hline $438 \mathrm{~A}-24-1,98$ & 4 & lower Pliocene & 2.67 & 4.2 & 9.8 & 5 & 7 & 39 & 158 & 0.91 & 1.9 & 3843 & 15.7 & 0.98 & 0.98 & 4.8 & 0.43 & 4.4 & 2.4 & 10 & 37 \\
\hline 438A-59-3, 67 & 5 & upper Miocene & 2.74 & 3.3 & 9.2 & 1.2 & 13 & 60 & 135 & 2.20 & 3.1 & 538 & 15.9 & 0.68 & 0.76 & 4.4 & 0.56 & 5.8 & 1.4 & 10 & 21 \\
\hline $438 \mathrm{~B}-4-1,77$ & 6 & & 3.28 & 2.8 & 9.6 & 20.2 & 50 & 42 & 137 & 2.62 & 2.7 & 465 & 12.7 & 0.70 & 0.34 & 3.4 & 0.45 & 3.4 & 1.3 & 7.5 & 16 \\
\hline $439-8-2,124$ & 7 & middle Miocene & 6.83 & 2.7 & 13.8 & 8.5 & 22 & 53 & 153 & 0.91 & 3.3 & 544 & 18.2 & 1.29 & 0.79 & 4.1 & 0.73 & 4.7 & 1.3 & 6.5 & 23 \\
\hline $439-11-3,71$ & 8 & & 2.84 & 3.2 & 9 & 4.2 & 6 & 52 & 193 & 0.83 & 3.2 & 608 & 18.1 & 0.96 & 0.74 & 4.9 & 0.59 & 4.9 & 2.0 & 8 & 24 \\
\hline \multicolumn{22}{|l|}{ Leg 87} \\
\hline $584-5-1,126-128$ & 1 & & 2.10 & 3.9 & 6.8 & 1.4 & 5.1 & 77 & 110 & 0.57 & 4.1 & 5554 & 17.2 & 0.86 & 0.66 & 3.9 & 0.44 & 7.6 & 2.8 & 17 & 26 \\
\hline $584-7-1,134-135$ & 2 & & 3.97 & 3.7 & 12.6 & 6.9 & 41.1 & 80 & 123 & 0.49 & 4.6 & 859 & 18.8 & 0.96 & 0.64 & 3.9 & 0.67 & 6.8 & 1.9 & 10 & 16 \\
\hline $584-9-1,67-69$ & 3 & & 3.15 & 5.3 & 13.7 & 2.5 & 1.7 & 45 & 121 & 1.91 & 4.8 & 631 & 9.6 & 1.29 & 0.73 & 3.6 & 0.29 & 3.2 & 1.3 & 11 & 13 \\
\hline $584-17, \mathrm{CC}$ & 4 & & 2.93 & 3.2 & 8.0 & 4.2 & 14.7 & 25 & 84 & 1.90 & 2.2 & 310 & 7.8 & 0.61 & 0.53 & 2.8 & 0.22 & 2.7 & 1.5 & 12 & 15 \\
\hline $584-27-2,27-28$ & 5 & lower Pliocene & 2.28 & 3.6 & 8.9 & 2.6 & 13.4 & 43 & 164 & 0.59 & 1.8 & 428 & 18.8 & 1.39 & 0.81 & 4.7 & 0.46 & 4.1 & 1.5 & 9 & 23 \\
\hline $584-28-4,14-16$ & 6 & & 3.76 & 3.2 & 9.2 & 3.8 & 22.4 & 48 & 127 & 1.39 & 3.1 & 481 & 15.2 & 1.22 & 0.76 & 3.7 & 0.37 & 4.6 & 1.5 & 12 & 20 \\
\hline $584-34-3,72-74$ & 7 & & 1.89 & 5.4 & 8.0 & 1.6 & 5.8 & 34 & 129 & 0.37 & 1.5 & 467 & 14.1 & 0.98 & 0.88 & 4.4 & 0.30 & 3.8 & 1.2 & 13 & 16 \\
\hline $584-36-5,83-85$ & 8 & & 2.2 & 3.9 & 5.2 & 2.3 & 20.3 & 81 & 84 & 0.58 & 3.9 & 841 & 18.9 & 0.50 & 0.76 & 3.3 & 0.79 & 8.9 & 2.8 & 11 & 25 \\
\hline $584-40-4,127-129$ & 9 & upper Miocene & 2.2 & 3.8 & 6.8 & 5.2 & 31.3 & 66 & 93 & 0.67 & 3.7 & 955 & 17.0 & 0.66 & 0.54 & 3.1 & 0.56 & 8.3 & 2.7 & 15 & 32 \\
\hline $584-83-2,48-50$ & 10 & upper Miocene & 3.54 & 5.2 & 11.6 & 3.2 & 12.3 & 47 & 128 & 0.70 & 2.4 & 577 & 15.5 & 1.36 & 0.70 & 3.9 & 0.48 & 5.3 & 1.6 & 11 & 22 \\
\hline
\end{tabular}

Note: $\mathrm{Na}_{2} \mathrm{O}$ and $\mathrm{Fe}_{2} \mathrm{O}_{3}$ in wt. \%, remainder in ppm; $\mathrm{Fe}_{2} \mathrm{O}_{3}=$ total $\mathrm{Fe}$ as $\mathrm{Fe}_{2} \mathrm{O}_{3}$.

Table 3. Trace element data (ppm) for international rock standards used for instrumental neutron activation analysis.

\begin{tabular}{|c|c|c|c|c|c|c|c|c|c|c|c|c|c|c|c|c|c|}
\hline Standards & $\mathrm{Fe}_{2} \mathrm{O}_{3}$ & $\mathrm{Na}_{2} \mathrm{O}$ & Sc & Co & $\mathrm{Ni}$ & $\mathrm{Rb}$ & $\mathrm{Zr}$ & $\mathrm{Sb}$ & $\mathrm{Ca}$ & $\mathrm{Ba}$ & $\mathrm{La}$ & $\mathrm{Eu}$ & $\mathrm{Tb}$ & $\mathrm{Hf}$ & $\mathrm{Ta}$ & Th & $\mathrm{U}$ \\
\hline GSN & 3.55 & 3.77 & 7.3 & 65 & 34 & 180 & 250 & 0.69 & 5.43 & 1380 & 70 & 0.69 & 0.54 & 6.5 & 2.81 & 40.8 & 7.74 \\
\hline BEN (Leg 57) & 12.26 & 3.3 & 24.5 & 62 & 267 & 42 & 356 & 0.32 & 0.63 & 982 & 76.2 & 3.9 & 1.17 & 5.8 & 6.6 & 9.8 & 2.17 \\
\hline BEN (Leg 87) & 11.65 & 4.2 & 24 & 57 & 254 & 42 & 277 & 0.27 & 0.63 & 938 & 74 & 3.74 & 1.04 & 5.3 & 6.2 & 9.8 & 2.3 \\
\hline $\mathrm{BEN}$ & 12.93 & 3.6 & 25.5 & 62 & 293 & 47 & 333 & 0.24 & 0.67 & 1019 & 80.7 & 3.83 & 1.15 & 5.9 & 6.8 & 10.5 & 2.46 \\
\hline
\end{tabular}

Note: Reference concentrations in GSN. Concentrations obtained in BEN using GSN reference concentrations.

Table 4. Instrumental neutron activation analysis of samples from Leg 87, Sites 582 and 583.

\begin{tabular}{|c|c|c|c|c|c|c|c|c|c|c|c|c|c|c|c|c|c|c|c|c|}
\hline $\begin{array}{l}\text { Core-Section } \\
\text { (interval in } \mathrm{cm} \text { ) }\end{array}$ & $\begin{array}{l}\text { Number } \\
\text { in Fig. } 9\end{array}$ & $\mathrm{Fe}_{2} \mathrm{O}_{3}$ & $\mathrm{Na}_{2} \mathrm{O}$ & $\mathrm{Sc}$ & Co & $\mathrm{Ni}$ & $\mathrm{Rb}$ & $\mathrm{Zr}$ & $\mathrm{Sb}$ & Cs & $\mathrm{Ba}$ & La & Eu & $\mathrm{Tb}$ & $\mathrm{Hf}$ & Ta & Th & U & $\mathrm{Th} / \mathrm{Ta}$ & $\mathrm{La} / \mathrm{Tb}$ \\
\hline $583 \mathrm{~A}-1-3,20-21$ & 1 & 1.77 & 3.7 & 6.9 & 2.1 & 3 & 119 & 144 & 0.41 & 7.6 & 519 & 23.9 & 0.6 & 0.53 & 4.4 & 0.79 & 11.4 & 2.63 & 14.5 & 45 \\
\hline $583 \mathrm{~A}-8-3,71-73$ & 2 & 3.80 & 4.5 & 12 & 4.9 & 7.7 & 136 & 283 & 0.96 & 7.7 & 706 & 30 & 1.5 & 0.85 & 7 & 1.23 & 13.8 & 3.99 & 11 & 35 \\
\hline $583 \mathrm{~A}-8-3,88-89$ & 3 & 3.89 & 3.8 & 12 & 6.2 & 18.9 & 95 & 232 & 0.43 & 4.9 & 458 & 24.3 & 1.2 & 0.86 & 6.2 & 0.85 & 9.7 & 2.34 & 11 & 28 \\
\hline $582 \mathrm{~B}-18-6,22-23$ & 4 & 1.50 & 3.9 & 6.3 & 1.8 & 2.9 & 89 & 159 & 0.70 & 4.2 & 452 & 16.3 & 0.5 & 0.64 & 5.2 & 0.50 & 8.5 & 2.37 & 17 & 25.5 \\
\hline $582 \mathrm{~B}-19-2,70-72$ & 5 & 2.53 & 4.4 & 11.3 & 2.2 & 5.3 & 86 & 222 & 0.32 & 3.8 & 421 & 22.6 & 1.3 & 0.94 & 6.1 & 0.80 & 8.8 & 2.18 & 11 & 24 \\
\hline $582 B-58-4,27-28$ & 6 & 1.75 & 4 & 5.2 & 2.7 & 6.8 & 82 & 126 & 0.67 & 5.1 & 410 & 14.4 & 0.5 & 0.34 & 4.9 & 0.48 & 6.8 & 1.90 & 14 & 42 \\
\hline
\end{tabular}

Note: $\mathrm{Na}_{2} \mathrm{O}$ and $\mathrm{Fe}_{2} \mathrm{O}_{3}$ in wt.\%, remainder in ppm; $\mathrm{Fe}_{2} \mathrm{O}_{3}=$ total $\mathrm{Fe}$ as $\mathrm{Fe}_{2} \mathrm{O}_{3}$. 


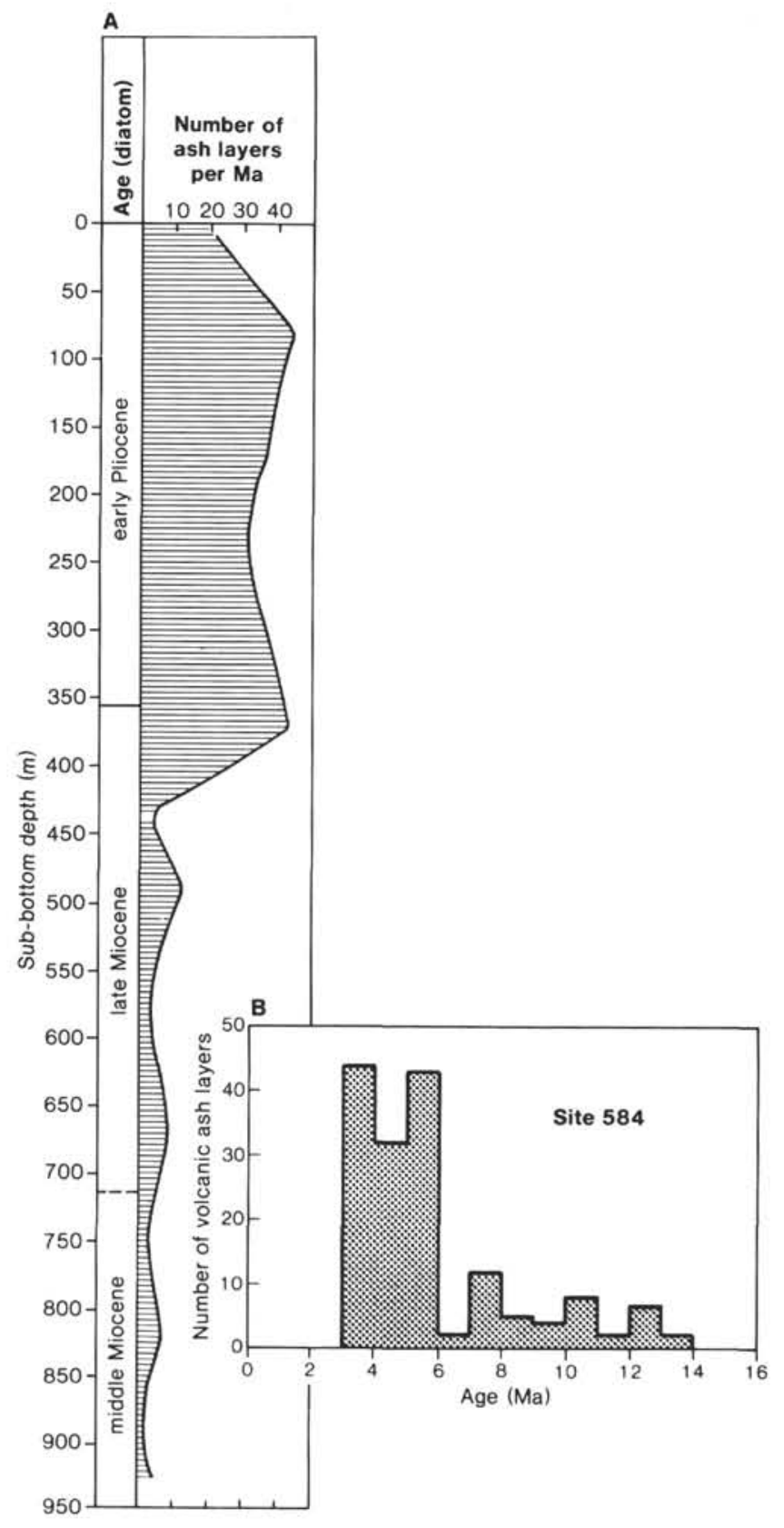

Figure 6. A. Frequency of volcanic ash layers versus sub-bottom depth at Site 584. B. Number of volcanic ash layers versus age of Site 584 sediments. Note the distinct peak from 6 to $3 \mathrm{Ma}$ indicating that explosive volcanism increases in the source area (northeastern Japan Arc) during Pliocene and late Miocene times.
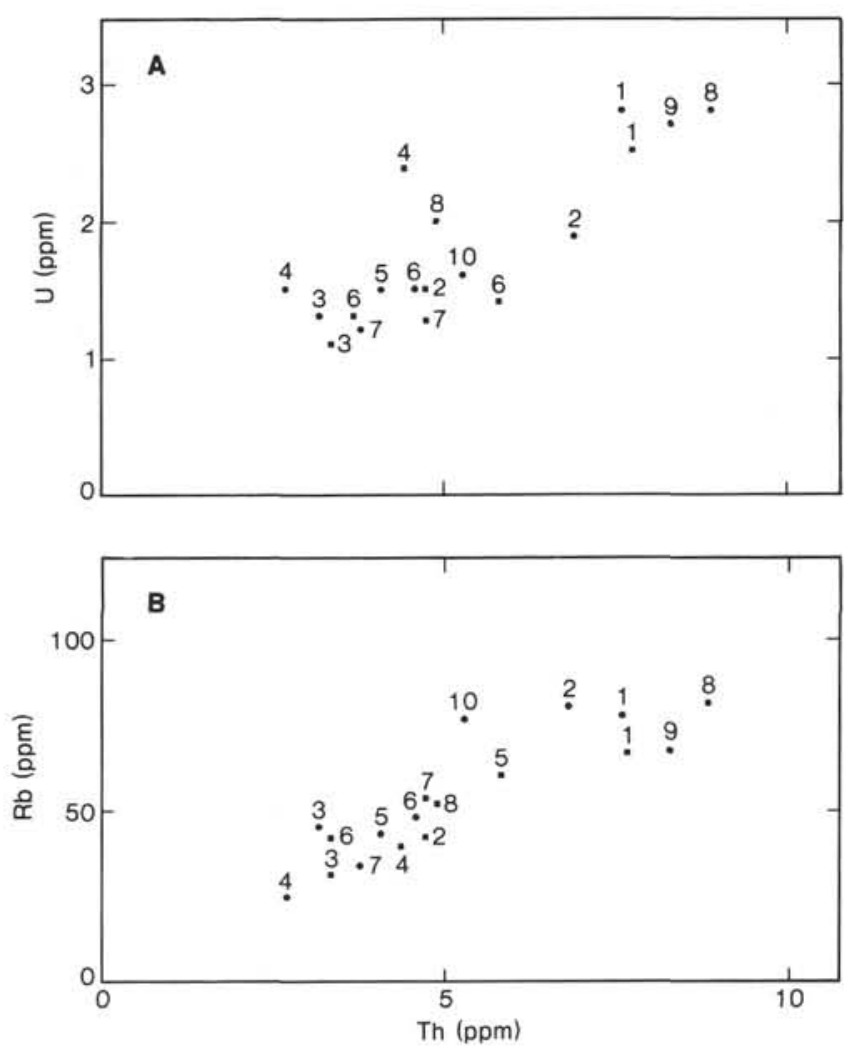

Figure 7. A. U versus Th. B. Rb versus Th. $\bullet$ Leg 87 , Site 584; • Leg 57, Sites 438, 439, and 440. See Table 2 for correlation of these sample numbers with DSDP designations. 

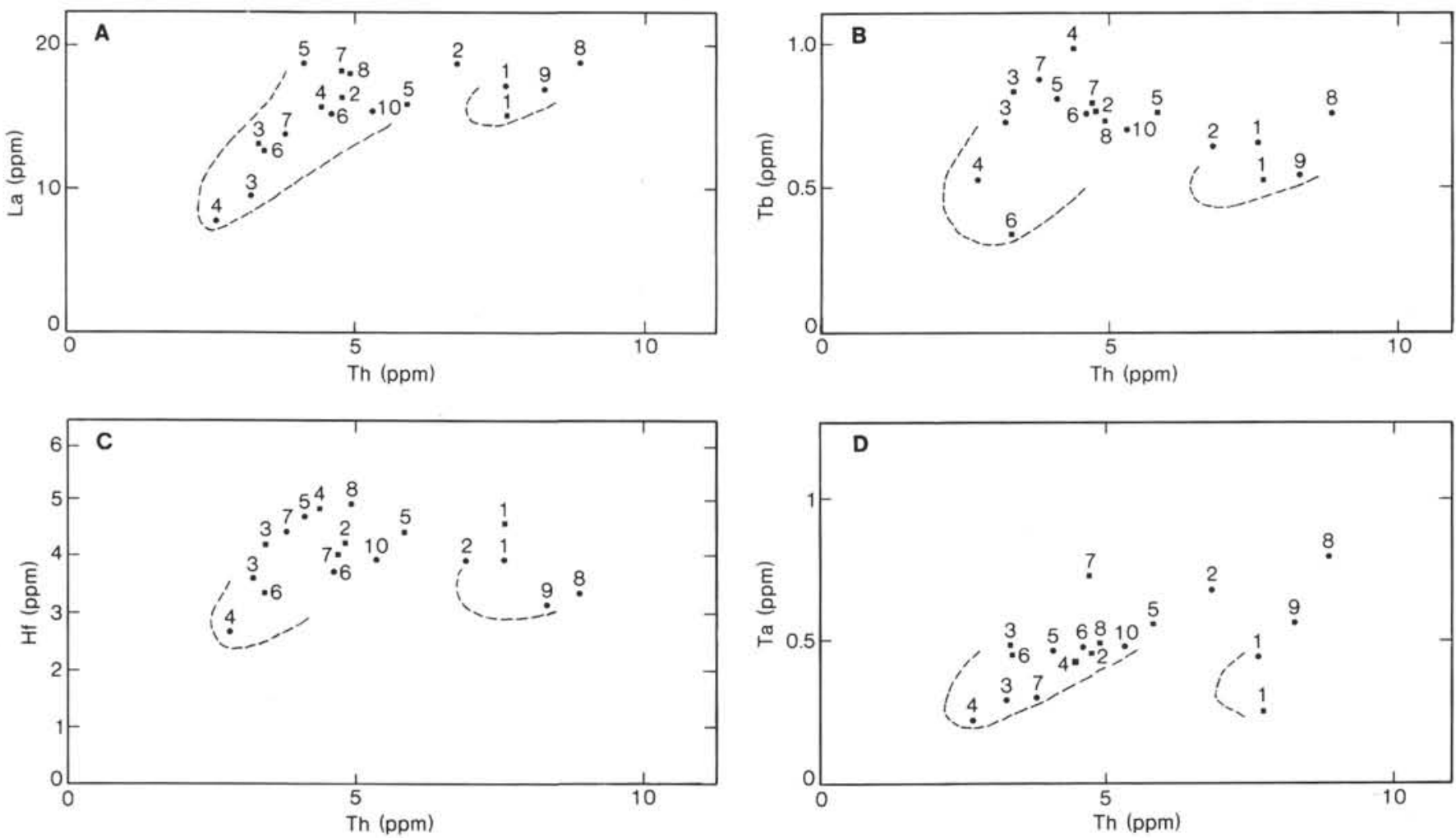

Figure 8. A. La versus Th. B. Tb versus Th. C. Hf versus Th. D. Ta versus Th. All symbols are as in Figure 7. Dashed lines represent lower limits of the group.
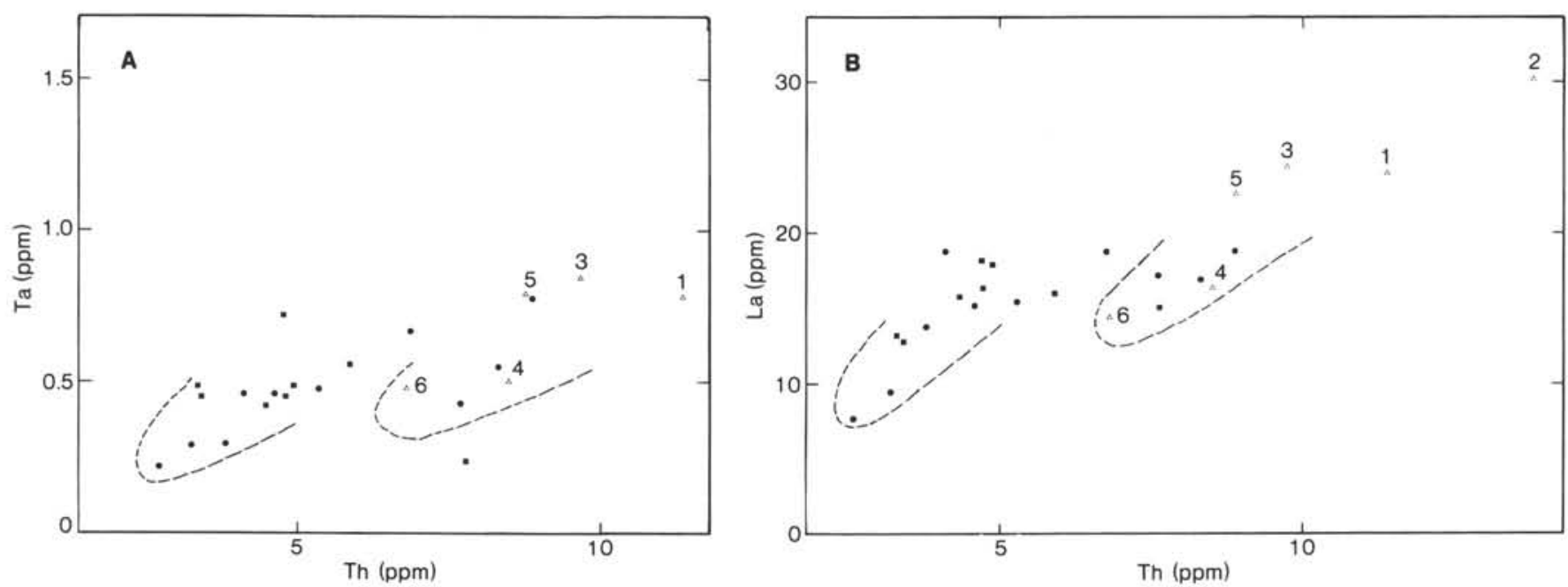

Figure 9. A. Ta versus Th. B. La versus Th. $\triangle$ Leg 87, Sites 582 and 583; • Leg 87, Site 584; $n$ Leg 57, Sites 438, 439, and 440. Dashed lines represent lower limits of the group. See Table 4 for correlation of these sample numbers with DSDP sample designations. 
APPENDIX

List of Observed Volcanic Ash, Site 584

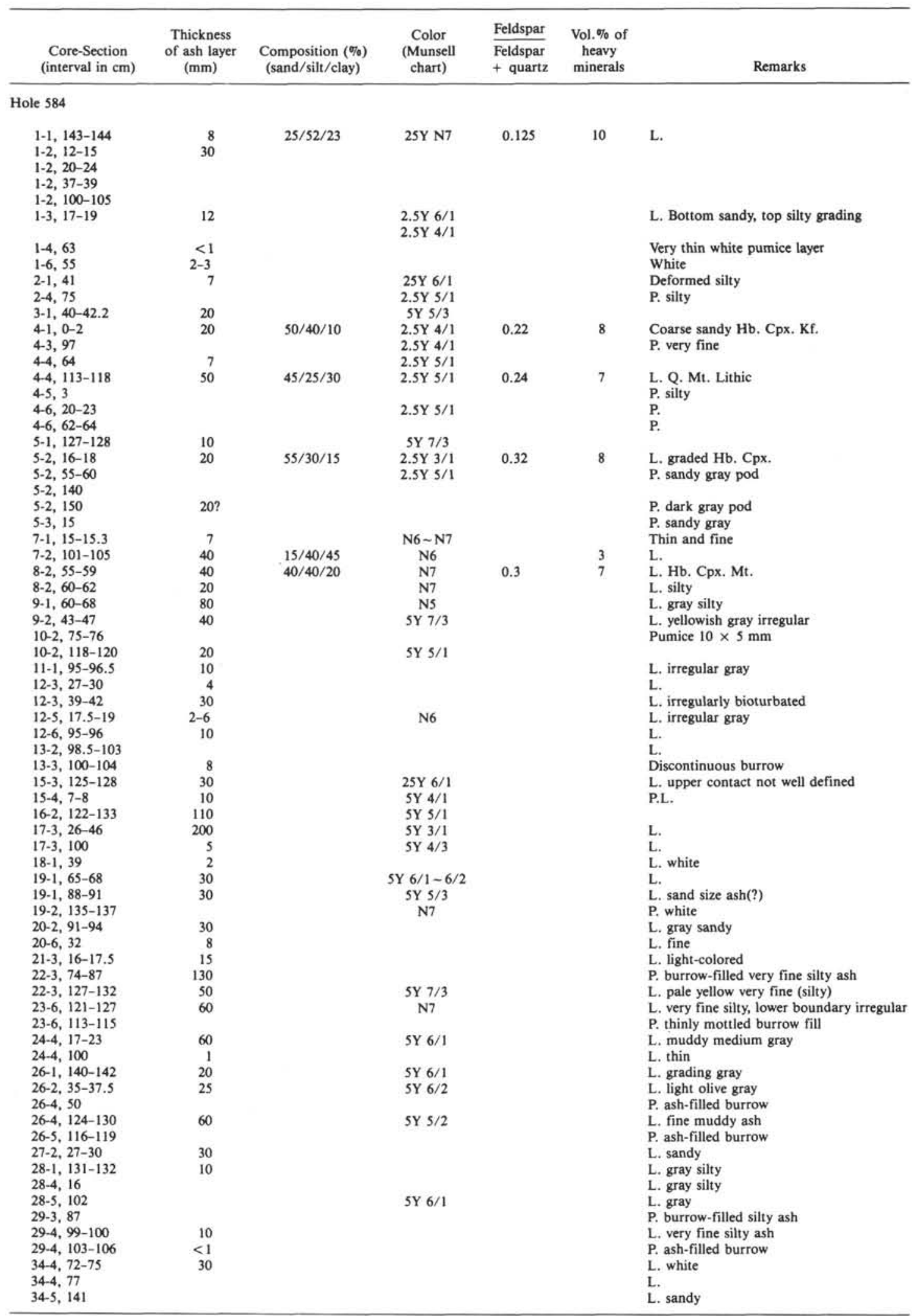


Appendix. (Continued).

\begin{tabular}{|c|c|c|c|c|c|c|}
\hline $\begin{array}{l}\text { Core-Section } \\
\text { (interval in cm) }\end{array}$ & $\begin{array}{l}\text { Thickness } \\
\text { of ash layer } \\
(\mathrm{mm})\end{array}$ & $\begin{array}{l}\text { Composition (\%) } \\
\text { (sand/silt/clay) }\end{array}$ & $\begin{array}{l}\text { Color } \\
\text { (Munsell } \\
\text { chart) }\end{array}$ & $\begin{array}{l}\text { Feldspar } \\
\text { Feldspar } \\
+ \text { quartz }\end{array}$ & $\begin{array}{l}\text { Vol. \% of } \\
\text { heavy } \\
\text { minerals }\end{array}$ & Remarks \\
\hline \multicolumn{7}{|l|}{ Hole 584 (Cont.) } \\
\hline $34-6,20-25$ & & & $\begin{array}{l}2.5 Y 4 / 1 \\
2.5 Y 7 / 1\end{array}$ & & & L. double layer \\
\hline $34-6,41-42$ & 7 & & $2.5 \mathrm{Y} 4 / 1$ & & & L. \\
\hline $35-1,26.5-28.5$ & 20 & & N7 & & & L. white fine silty \\
\hline $35-1,33-36$ & 30 & & N6 & & & P. silty \\
\hline $35-1,50$ & & & N5 & & & P. silty \\
\hline $35-2,57-58$ & 10 & & N6 & & & L. silty \\
\hline $35-3,97-101$ & 40 & & $\mathrm{~N} 6 / 2$ & & & L. \\
\hline $35-3,101-103$ & 20 & & $6 / 2$ & & & L. \\
\hline $36-2,28-32$ & 40 & & $\mathrm{~N} 6 / 2$ & & & L. silty \\
\hline $36-2,100-101$ & & & $\mathrm{~N} 6 / 1$ & & & P. \\
\hline $36-2,134-137$ & 30 & & $\mathrm{~N} 6 / 1$ & & & P. \\
\hline $36-4,26-27$ & 10 & & $\mathrm{~N} 5 / 1$ & & & L. silty \\
\hline $36-5,20-21$ & 10 & & & & & Gray green diffuse ash \\
\hline $36-5,80-84$ & 40 & & & & & L. gray \\
\hline $37-2,123-124$ & 40 & & & & & L. white \\
\hline $37-3,42-42.5$ & 6 & & $5 Y 5 / 2$ & & & L. fine \\
\hline $37-4,16-19$ & 30 & & N7 & & & L. very fine \\
\hline $37-4,111-114$ & 26 & & N7 & & & L. silty \\
\hline $37-5,69.5-70.6$ & 11 & & N7 & & & P. thin laminated silty \\
\hline $37-5,89-94$ & 50 & & $5 Y 7 / 2$ & & & L. light gray very fine \\
\hline $38-1,41-43$ & 20 & & N6 & & & P. gray silty \\
\hline $38-1,76$ & $2-3$ & & N6 & & & L. gray \\
\hline $38-4,41-43$ & & & & & & P. gray sandy \\
\hline $38-5,25-5$ & 10 & & & & & L. sandy \\
\hline $38-5,30-31$ & 10 & & & & & L. gray sandy \\
\hline $38-5,59-69$ & 100 & & & & & L. silty \\
\hline $39-2,10-11$ & 10 & & & & & P. silty \\
\hline $39-2,38-40$ & 10 & & N7 & & & L. white silty \\
\hline $39, \mathrm{CC}, 20-24.5$ & 45 & & & & & L. gray silty \\
\hline $40-4,27$ & 2 & & & & & L. sandy \\
\hline $40-4,129.5-131.5$ & 20 & & & & & L. gray sandy \\
\hline $40-1,43-47$ & 40 & & & & & L. gray fine sandy \\
\hline $42-1,58-61$ & 30 & & & & & L. sandy inclined \\
\hline $43-1,26-29$ & 30 & & & & & L. gray silty \\
\hline $43-1,75$ & 10 & & & & & L. gray silty \\
\hline $48-4,45-47$ & 20 & & & & & L. upper contact indistinct light gray \\
\hline $49-3,12-16$ & 30 & & & & & L. \\
\hline $49-3,58$ & 10 & & & & & L. gray \\
\hline $49-4,79-86$ & 10 & & $\mathrm{~N} 4$ & & & L. volcanic sand \\
\hline $50-1,92-93$ & 10 & & N8 & & & L. \\
\hline $52-2,64$ & 2 & & N7 & & & L. \\
\hline $52-3,77-83$ & so & & & & & L. \\
\hline $52-2,77$ & 10 & & N6 & & & P. burrow filling \\
\hline $53-2,32-45$ & 130 & & & & & L. dark gray \\
\hline $53-3,65-70$ & 10 & & $\mathrm{~N} 5 / 2$ & & & P. \\
\hline $54-1,80-85$ & 15 & & & & & L. inclined, fine gray \\
\hline $54-3,145-150$ & & & & & & L. silty \\
\hline $54-5,118-124$ & 50 & & N6-N7 & & & L. sandy silty white \\
\hline $54-5,130$ & 10 & & & & & L. offset of heated fracture \\
\hline $54-6,47-50$ & 30 & & N5 & & & P. sandy \\
\hline $54-6,99-100$ & 10 & & N6-7 & & & P. sandy \\
\hline $54-6,112-113$ & 10 & & N6-N7 & & & P. \\
\hline $55-5,117-120$ & 30 & & & & & L. gray sandy \\
\hline $56-2,75-90$ & & & & & & P. ash-filled burrows \\
\hline $56-4,100-105$ & 2 & & & & & P. \\
\hline $60-1,124$ & $<10$ & & & & & L. \\
\hline $62-1,74-78$ & 25 & & N5 & & & P. \\
\hline $62-3,55-60$ & 15 & & N6 & & & L. burrowed silty \\
\hline $71-1,125-133$ & 5 & & N8 & & & L. silty \\
\hline $78-2,22$ & $<10$ & & & & & L. sandy black (?) \\
\hline $79-3,15-20$ & 10 & & & & & P. \\
\hline $80-1,126-131$ & 5 & & N6 & & & P. \\
\hline $81-2,118$ & $<10$ & & & & & $\mathrm{P}$. \\
\hline $83-2,50-53$ & 20 & & & & & L. gray sandy \\
\hline $83-5,0-3$ & 30 & & & & & P. sandy \\
\hline $88-1,138-143$ & 8 & & N6 & & & L. silty \\
\hline $88-2,130$ & & & & & & P. burrow filled \\
\hline $90-1,102-104$ & 20 & & $5 \mathrm{GY} 3 / 2$ & & & L. silty \\
\hline $91-1,16-19$ & 20 & & & & & L. sandy \\
\hline $95-1,20-25$ & 50 & & & & & L. sandy \\
\hline $96-2,41-45$ & 40 & & N7 & & & L. silty dark green lamina \\
\hline \multicolumn{7}{|l|}{ Hole $584 \mathrm{~A}$} \\
\hline $2-2,61-68$ & 38 & & N6-N7 & & & L. silty \\
\hline $2-2,64-66$ & 12 & & N8 & & & L. silty \\
\hline
\end{tabular}

Note: Column $\mathrm{F} /(\mathrm{F}+\mathrm{Q})$ shows the ratio between quartz and feldspar determined by $\mathrm{X}$-ray diffraction (Matsumoto, this volume). L. $=$ layer, $\mathrm{P}$. = pod or pocket, $\mathrm{Hb}$. = Hornblende, $\mathrm{Cpx}$. = Clinopyroxene, $\mathrm{Kf} .=\mathrm{K}$-feldspar, $\mathrm{M}$. = Magnetite. 

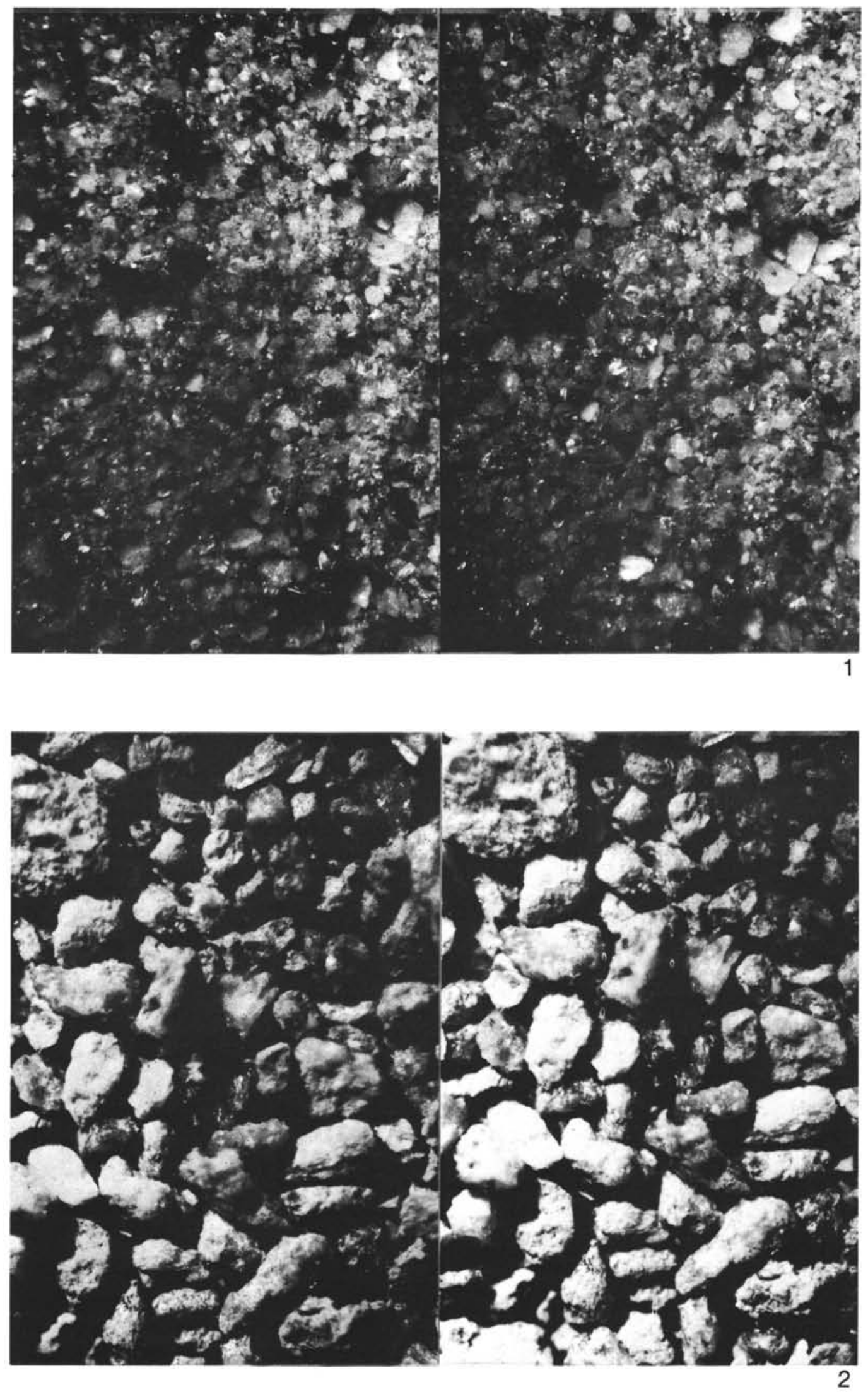

Plate 1. 1. Stereographic photograph of some volcanic ash layers (rich in bubble-wall type shards) obtained from Site 584; scale is about 5 mm from top to bottom of the photo. 2. Stereographic photograph of the volcanic ash layer (rich in pumice-type shards) obtained from Site 584; scale same as in previous figure. 